\title{
Effects of Fat, Beef and Fiber in Diets on Activities of Sphingomyelinase, Ceramidase and Caspase-3 in Rat Colonic Mucosa
}

\author{
Liping Yang ${ }^{a}$ Marja Mutanen ${ }^{b}$ Yajun Cheng ${ }^{a}$ Rui-Dong Duan ${ }^{a}$ \\ aBiomedical Center, B11, University of Lund, Sweden; b Department of Applied Chemistry and Microbiology, \\ Nutrition, University of Helsinki, Finland
}

\section{Key Words}

Sphingomyelinase $\cdot$ Caspase-3. Ceramidase $\cdot$ Fat $\cdot$ Red meat · Fiber · Colon

\begin{abstract}
Objective: The present study investigates the activity changes of sphingomyelinase (SMase), ceramidase and caspase- 3 in colonic mucosa of rats induced by high fat and red meat diets. Method: For a period of 3 weeks, rats were fed protein without fat (control), high fat only, high fat with beef, and high fat with fiber (cellulose) diets. The fat content $(22.4 \%)$ was constant in the three high fat diets. Then, the colonic mucosae were scraped and homogenized and the activities of SMase, ceramidase and caspase- 3 determined. Results: Compared to the control diet, the fat diet and fat with beef diet reduced intestinal alkaline SMase by 80 and $84 \%$, respectively; ceramidase activity by 60 and $92 \%$, respectively, and caspase- 3 activity by 40 and $75 \%$, respectively. The activities of acid and neutral SMases were also decreased by fat and fat with beef diets but to a smaller extent than those of alkaline SMase. Supplement of fiber in the fat diet had no effect on the changes of alkaline SMase activity but prevented fat-induced decreases in acid and neu-
\end{abstract}

tral SMase activities and partially prevented those of ceramidase and caspase-3 activities. The activity of intestinal alkaline phosphatase was not changed by any of the diets. Conclusion: Fat, beef and fiber significantly affect the enzymes responsible for sphingomyelin metabolism and apoptosis in the colon. The effects may have implications in colonic tumorigenesis related to dietary factors.

Copyright $\odot 2002$ S. Karger AG, Basel

\section{Introduction}

A high fat diet influences the risk of colorectal cancer as do other dietary components, such as red meat and fiber. Sphingomyelin (SM) metabolism is a novel signal transduction pathway that may have impact on colonic tumorigenesis [1]. Although several factors such as calcium, bile salts, and short chain fatty acids have been thought to be involved, the biochemical mechanism by which red meat and fiber affect fat-promoted tumorigenesis in the colon has not been established.

SM metabolism triggered by sphingomyelinase (SMase) represents a novel signal transduction pathway that generates multiple lipid messengers such as ceramide

\begin{tabular}{ll}
\hline KARGER & ( ) 2002 S. Karger AG, Basel \\
$1011-7571 / 02 / 0113-0150 \$ 18.50 / 0$ \\
$\begin{array}{l}\text { Fax +41613061234 } \\
\begin{array}{l}\text { E-Mail karger@karger.ch } \\
\text { www.karger.com }\end{array}\end{array}$ & $\begin{array}{l}\text { Accessible online at: } \\
\text { www.karger.com/journals/mpp }\end{array}$
\end{tabular}

Rui-Dong Duan, MD, PhD

Biomedical Center B11

University of Lund

S-221 84 Lund (Sweden)

Tel. +46 46222 0709, Fax +46 46 137277, E-Mail rui-dong.duan@med.lu.se 
Table 1. Nutrient composition of experimental diets $(\%)$

\begin{tabular}{lcccc}
\hline Ingredients & \multicolumn{2}{l}{ Type of diet } & & \\
\cline { 2 - 5 } & control & fat & fat with beef & fat with fiber \\
\hline Protein & 20.7 & 23.6 (casein) & 24.0 (beef) & 21.2 (casein) \\
Butter & - & 14.9 & 14.9 & 13.4 \\
Sunflower oil & - & 1.3 & 1.3 & 1.2 \\
Rapeseed oil & - & 6.2 & 6.2 & 5.6 \\
Crude oil & 4.4 & - & - & - \\
Carbohydrate & 53.4 & 47.5 & 47.5 & 42.8 \\
Fiber & 3.7 & - & - & 10.0 \\
Mineral mixture & 4.2 & 4.2 & 4.2 & 3.8 \\
Vitamin mixture & 1.2 & 1.2 & 1.2 & 1.0 \\
\hline
\end{tabular}

In the control diet, the proteins are a mixture of soybean, casein, and fish meat. The fiber is crude fiber. In the high fat with fiber diet, the fiber is cellulose. In addition, the moisture of the control diet is $12 \%$. and sphingosine [2]. Ceramide may inhibit cell proliferation and induce cell differentiation and apoptosis by activation of ceramide-activated protein kinase, ceramideactivated protein phosphatase, Raf kinase and caspases $[3,4]$. The cellular levels of ceramide are mainly determined by SMase and ceramidase; the latter can catalyze both hydrolysis and biosynthesis of ceramide [5]. Studies have indicated that the SM pathway may have implications for colon cancer development [6, 7]. Chemical carcinogens cause an accumulation of SM in the colonic mucosa associated with a reduction of neutral SMase activity [8]. A supplement of SM or ceramide analogues in the diet inhibits colonic tumorigenesis induced by chemical carcinogens $[9,10]$. In human colorectal adenoma, carcinoma and familial adenomatous polyposis, tissue activities of SMases are significantly decreased [11, 12]. The present study aimed to investigate whether fat, beef or fiber in the diet has any effect on the activities of SMase, ceramidase or caspase-3. The latter is a key enzyme in the execution phase of apoptosis [13].

\section{Materials and Methods}

\section{Materials}

Female Sprague-Dawley rats weighing about $200 \mathrm{~g}$ were obtained from Möllegård (Ry, Denmark) and housed in a temperature-controlled room under a 12-hour light and dark rhythm with free access to water. Phenylmethylsulfonylfluoride (PMSF), benzamidine, taurocholate (TC), 3-[(3-cholamidopropyl)dimethylammoniol]-1-propanesulfonate (CHAPS), $p$-nitrophenyl phosphate (pNPP), p-nitrophenyl, $p$-nitroaniline (pNA), Triton X-100 (TX-100) and dithiothreitol were purchased from Sigma Co. (St. Louis, Mo., USA). The purified SM was choline-labeled with $\left[\mathrm{N}-{ }^{14} \mathrm{C}-\mathrm{CH}_{3}\right]$ by the methods of
Stoffel [14] and the specific activity of labeled SM $\left[{ }^{14} \mathrm{C}-\mathrm{SM}\right]$ was $56 \mu \mathrm{Ci} / \mathrm{mg}$. The ${ }^{14} \mathrm{C}$-palmitoyl-labeled ceramide $\left[{ }^{14} \mathrm{C}-\mathrm{C}\right.$ - $]$ ] was prepared by Peter Ström at Astra-Draco (Lund, Sweden) with the specific activity being $45 \mathrm{mCi} / \mathrm{mmol}$ [15]. The caspase-3 substrate, $\mathrm{N}$ acetyl-Asp-Glu-Val-Asp-pNA (Ac-DEVD-pNA), and caspase-3 inhibitor (DEVD-CHO) were purchased from Calbiochem (Stockholm, Sweden).

\section{Animal Diets}

Three types of diet were prepared; namely, a high fat diet, a high fat diet with beef, and a high fat diet with fiber (cellulose). The preparation of these diets has been described in detail elsewhere [16]. The fat used was a mixture of butter, rapeseed oil and sunflower seed oil that provides an intake of saturated, monounsaturated and polyunsaturated fatty acids in the ratio of $3: 2: 1$, which corresponds to the intake of these fatty acids in the Western-type diet. Casein or freezedried low fat beef (Musculus longissimus dorsi) was minced and added to the fat mixture such that the diets contained similar amounts of protein and carbohydrate with respect to energy intake. For preparation of the fiber diet, cellulose was mixed with the high fat diet containing casein. These diets were stored at $-20^{\circ} \mathrm{C}$ and given to the animals daily. The control diet was a standard commercial diet from B\&K Universal AB (Sollentuna, Sweden). The compositions of various diets are listed in table 1 .

\section{Animal Treatment and Sample Preparation}

Rats were randomly divided into four groups of 9 animals. The rats were fed one of the four types of diets for 3 weeks. The body weight was measured weekly. At the end of the experiment, rats were anesthetized with diethyl ether, the colon was removed, cut open longitudinally, and rinsed with ice-cold $0.15 M \mathrm{NaCl}$ containing $1 \mathrm{mM}$ benzamidine. The colonic mucosa was gently scraped and homogenized in $0.25 M$ sucrose buffer containing $5 \mathrm{mM} \mathrm{MgCl}, 0.15 M \mathrm{KCl}$, $50 \mathrm{~m} M \mathrm{~K}_{2} \mathrm{HPO}_{4}, 1 \mathrm{~m} M$ PMSF, $1 \mathrm{~m} M$ benzamidine and $6 \mathrm{~m} M$ TC, $\mathrm{pH} 7.4$, followed by centrifugation at 5,000 rpm for $20 \mathrm{~min}$ [17]. The supernatant was used for enzyme activity assay and protein determination. 
Assay for SMase Activity

SMase activity was determined according to Duan and Nilsson [18]. For alkaline SMase assay, a $5-\mu 1$ sample was added to $75 \mu 1$ of $50 \mathrm{~m} M$ Tris- $\mathrm{HCl}$ buffer containing $0.15 \mathrm{M} \mathrm{NaCl}, 2 \mathrm{~m} M$ EDTA and $6 \mathrm{~m} M \mathrm{TC}, \mathrm{pH} 9.0$. The reaction was started by addition of $20 \mu \mathrm{l}$ of $\left[{ }^{14} \mathrm{C}-\mathrm{SM}\right](80 \mathrm{pmol}, 8,000 \mathrm{dpm})$ in the assay buffer. After incubation at $37^{\circ} \mathrm{C}$ for $30 \mathrm{~min}$, the reaction was terminated by addition of $0.4 \mathrm{ml}$ of $2: 1$ chloroform/method $(\mathrm{v} / \mathrm{v})$, followed by centrifugation at $10,000 \mathrm{rpm}$ for $5 \mathrm{~s}$. An aliquot $(100 \mu \mathrm{l})$ of the upper phase containing the cleaved phosphocholine was taken, and the radioactivity was estimated by liquid scintillation counting. The activities of acid and neutral SMases were measured by the procedure described above but with modifications to the buffers. Acid SMase activity was assayed in $50 \mathrm{~m} M$ Tris-maleate buffer (pH 5.0) containing $0.15 \mathrm{M} \mathrm{NaCl}$ and $6 \mathrm{~m} M$ TC. Neutral SMase activity was determined in $50 \mathrm{~m} M$ Tris$\mathrm{HCl}$ buffer ( $\mathrm{pH} 7.4$ ) containing $0.15 \mathrm{M} \mathrm{NaCl}, 2 \mathrm{mM} \mathrm{MgCl}$, and $0.12 \%$ TX-100. TX-100 at this concentration fully activates neutral SMase, but abolishes the activity of intestinal alkaline SMase [18].

\section{Assay of Neutral Ceramidase Activity}

The assay of ceramidase activity was a modification of a method reported previously [18]. $\left[{ }^{14} \mathrm{C}-\mathrm{Cer}\right]$ (10 pmol with $\left.18,000 \mathrm{dpm}\right)$ was dried under nitrogen and suspended in $95 \mu 1$ of $50 \mathrm{~m} M$ Tris-maleate buffer containing $10 \mathrm{~m} M \mathrm{TC}, \mathrm{pH} 7.0$, followed by sonication for $2 \mathrm{~min}$. Samples were added in the buffer and incubated at $37^{\circ} \mathrm{C}$ for $1 \mathrm{~h}$. The reaction was terminated by addition of $0.6 \mathrm{ml}$ of methanol/ chloroform/heptane $(28 / 25 / 20, \mathrm{v} / \mathrm{v} / \mathrm{v})$ and $0.2 \mathrm{ml}$ of $0.05 \mathrm{M}$ $\left(\mathrm{K}_{2} \mathrm{CO}_{3}+\mathrm{K}_{2} \mathrm{~B}_{2} \mathrm{O}_{4}\right)-\mathrm{KOH}, \mathrm{pH} 10$, according to Belfrage and Vaughan [19]. After centrifugation, $200 \mu \mathrm{l}$ of the upper phase was taken and the radioactivities were measured by liquid scintillation counting. The hydrolysis of ceramide was calculated and ceramidase activity was expressed in units of released fatty acids per hour per milligram of sample proteins.

\section{Assay of Caspase-3 Activity}

The caspase- 3 activity was determined as described previously [20]. A sample in $20 \mu \mathrm{l}$ was added to $100 \mu \mathrm{l}$ of $50 \mathrm{~m} M$ HEPES buffer containing $0.1 \mathrm{M} \mathrm{NaCl}, 0.1 \%$ CHAPS, $10 \mathrm{~m} M$ dithiothreitol, $0.1 \mathrm{~m} M$ EDTA, $10 \%$ glycerol, $\mathrm{pH} 7.4$, in a microplate. The reaction was started by adding $10 \mu \mathrm{l}$ of Ac-DEVD-pNA to a final concentration of $200 \mu M$, and the absorbance at $405 \mathrm{~nm}$ was measured every $5 \mathrm{~min}$ over a period of $30 \mathrm{~min}$ using a microplate reader (Bio-Rad, Hercules, Calif., USA). The rate of change and absorbance was determined and caspase- 3 activity was calculated. To verify the activity of caspase- 3 , in another set of assays, $20 \mu \mathrm{l}$ of the samples were preincubated with $10 \mu \mathrm{l}(500 \mathrm{n} M)$ of DEVD-CHO, a caspase-3 inhibitor, in the assay buffer for $10 \mathrm{~min}$. The remaining activity was determined as described above.

\section{Assay of Alkaline Phosphatase Activity and Protein}

Alkaline phosphatase activity was determined with pNPP as substrate. In $200 \mu \mathrm{l}$ of $50 \mathrm{~m} M$ glycine buffer, $\mathrm{pH} 10.0,25 \mu \mathrm{l}$ of $100 \mathrm{mM}$ pNPP and $20 \mu 1$ of sample were added and mixed. After incubation at $37^{\circ} \mathrm{C}$ for $30 \mathrm{~min}$, the reaction was terminated by addition of $1 \mathrm{ml}$ of $0.2 \mathrm{M} \mathrm{NaOH}$. The optical density was determined at $405 \mathrm{~nm}$ by a Bio-Rad Microplate Reader. Protein amounts were determined using a Bio-Rad DC protein assay kit, with bovine serum albumin as a standard.

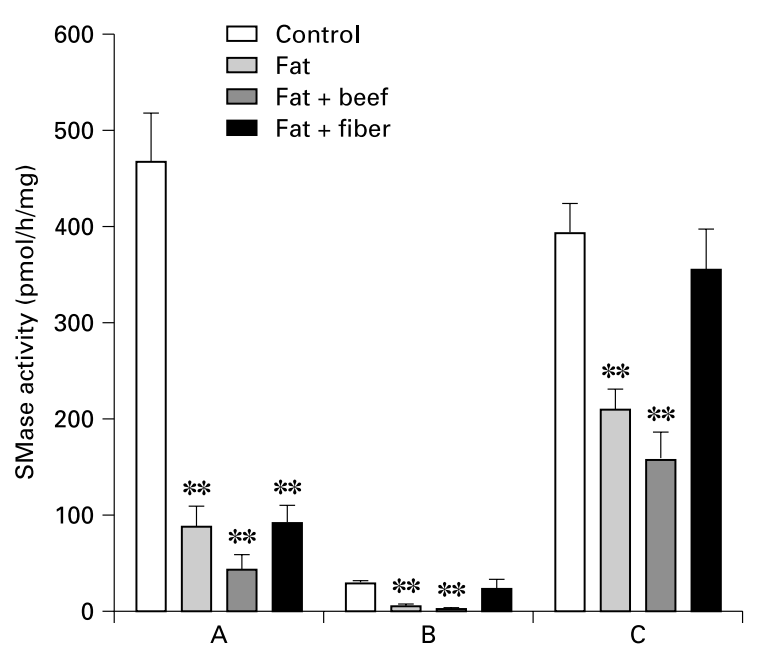

Fig. 1. The activities of SMases in colonic mucosa of rats fed for 3 weeks with normal diet, fat diet, fat diet with beef and fat diet with fiber. Activities of acid, neutral and alkaline SMase were determined, using $\left[{ }^{14} \mathrm{C}-\mathrm{SM}\right]$ as substrate. ${ }^{* *} \mathrm{p}<0.005$ as compared with normal diet. Results are mean \pm SE from 9 rats in each group. A Alkaline SMase. B Neutral SMase. C Acid SMase.

\section{Statistical Analysis}

The results are expressed as mean \pm standard error of the mean (SEM). The statistical analysis was performed by unpaired Student's $t$ test and $p<0.05$ was considered significant.

\section{Results}

\section{Body Weight of Rats}

The mean body weight of the rats in the beginning of the experiment was $210 \pm 3.3 \mathrm{~g}$. At the end of the experiment, the mean body weight was $243 \pm 10.0 \mathrm{~g}$ (control group), $251 \pm 12.1 \mathrm{~g}$ (fat group), $253 \pm 15.8 \mathrm{~g}$ (fat plus beef group), and $246 \pm 14.2 \mathrm{~g}$ (fat plus fiber group). The difference in body weight between the four groups was not significant $(\mathrm{p}>0.05)$ under the experimental conditions.

\section{Activity of SMase in the Colon of Rats}

The fat diet, fat plus beef diet, and fat plus fiber diet reduced alkaline SMase from $480 \pm 30 \mathrm{pmol} / \mathrm{h} / \mathrm{mg}$ to 80 $\pm 20,10 \pm 5$, and $80 \pm 15$, respectively (fig. 1A). These reductions were statistically significant $(\mathrm{p}<0.005)$. The corresponding neutral SMase activities were $27.2 \pm 8.2$ (controls), $7.8 \pm 0.5$ (fat alone), $5.3 \pm 0.1$ (fat plus beef), 


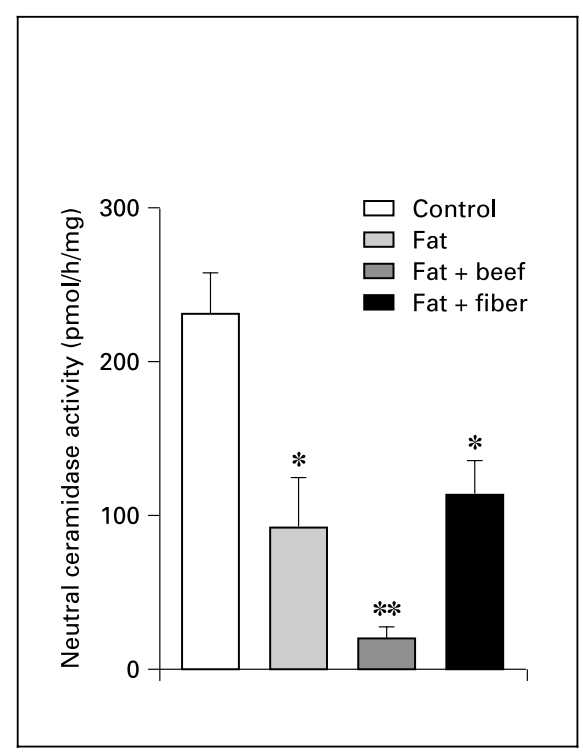

Fig. 2. The activity of neutral ceramidase in colonic mucosa of rats fed with normal diet, fat diet, fat diet with beef or fiber, respectively, for 3 weeks. The ceramidase activity in the supernatant was determined using $\left[{ }^{14} \mathrm{C}\right.$ Cer] as substrate. ${ }^{*} \mathrm{p}<0.05,{ }^{* *} \mathrm{p}<0.005$ as compared with normal diet. Results are mean \pm SE from 9 rats in each group.

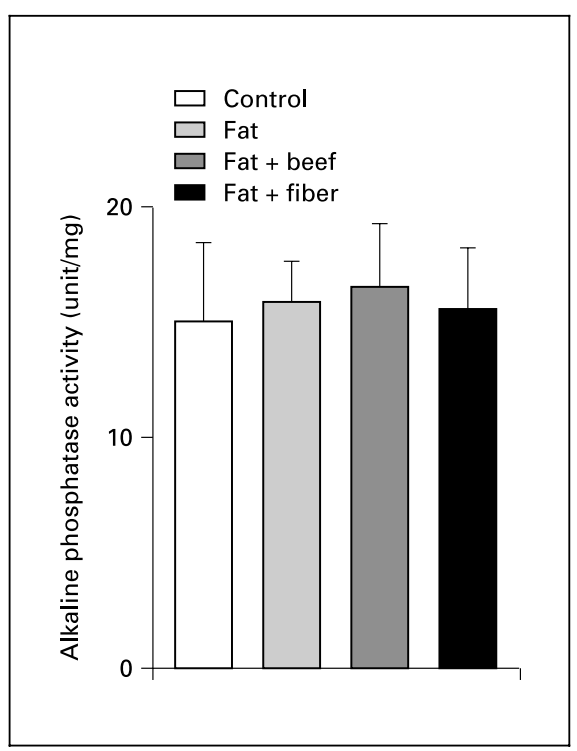

Fig. 3. Alkaline phosphatase activity in the colonic mucosa of rats fed control diet, fat diet, fat diet with beef or fiber, respectively, for 3 weeks. The alkaline phosphatase activity in the supernatant was determined with pNPP as substrate. Results are mean $\pm \mathrm{SE}$ from 9 rats in each group. and $22.5 \pm 9.1$ (fat plus fiber). The changes induced by fat diet and fat plus beef diet were significant $(p<0.005$; fig. 1B). The acid SMase activities of the controls, fat, fat plus beef, and fat plus fiber diets were $400 \pm 10,200 \pm 8$, $160 \pm 15$ and $380 \pm 30$, respectively (fig. 1C). The reductions caused by the fat diet and fat plus beef diet were statistically significant $(p<0.005)$. Apparently, the fat plus fiber diet did not induce significant change in the activities of both neutral and acid SMase (fig. 1B and C).

\section{Changes of Ceramidase Activity in the Colon of Rats}

As shown in figure 2, the fat diet, fat plus beef diet, and fat plus fiber diet decreased the ceramidase activity from $230 \pm 28$ to $94 \pm 31$, to $18 \pm 6$ and $117 \pm 24 \mathrm{pmol} / \mathrm{h} / \mathrm{mg}$, respectively. The reduction of ceramidase activity by fat diet and fat plus fiber diet was similar (approximately $60 \%$ ); however, the reduction induced by fat plus beef was $80 \%$.

\section{Alkaline Phosphatase Activity in the Colon of Rats}

The activities of alkaline phosphatase of the control, fat, fat plus beef, and fat plus fiber were $15.0 \pm 3.1,15.7$ $\pm 1.9,16.3 \pm 2.7$ and $15.5 \pm 2.5$ units $/ \mathrm{mg}$, respectively
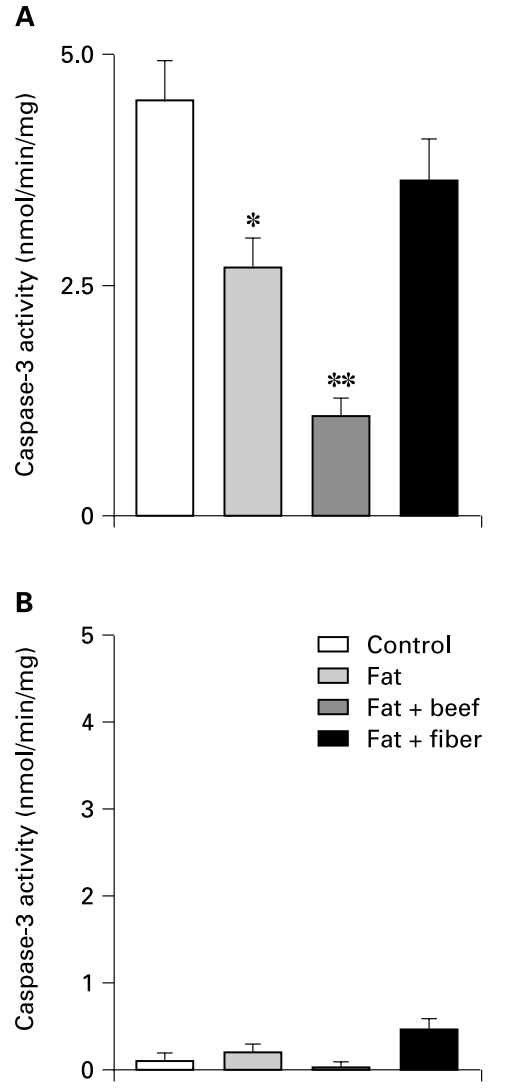

Fig. 4. The activity of caspase- 3 in the colonic mucosa or rats fed control diet, fat diet, fat diet with beef or fiber, respectively, for 3 weeks. Caspase-3 activity was determined using DEVD-pNA as substrate (A). To verify the activity, the same samples were preincubated with DEVD-CHO, a caspase-3 inhibitor, for $10 \mathrm{~min}$, followed by assaying the remaining activity of caspase-3 (B). Results are mean \pm SE from 9 rats in each group. ${ }^{*} \mathrm{p}<0.05,{ }^{* *} \mathrm{p}<0.005$ as compared with normal diet.

(fig. 3). Therefore, the experimental diet did not induce any change in the level of alkaline phosphatase activity, compared to the control diet.

\section{Caspase-3 Activity in the Colon of Rats}

As shown in figure $4 \mathrm{~A}$, the fat diet, fat plus beef diet, and the fat plus fiber diet reduced the caspase- 3 activity from $4.6 \pm 0.4$ to $2.8 \pm 0.3$, to $1.1 \pm 0.2$, and $3.7 \pm 0.5$ $\mathrm{nmol} / \mathrm{min} / \mathrm{mg}$, respectively. Reductions caused by the fat 
diet $(40 \%)$ and fat plus beef diet $(75 \%)$ were higher than those of fat plus fiber (20\%). To verify that the activities determined were those induced by caspase-3, samples were pretreated with caspase- 3 inhibitor for $10 \mathrm{~min}$. As shown in figure $4 \mathrm{~B}$, the caspase- 3 inhibitor effectively inhibited the activity of caspase- 3 in all of the groups.

\section{Discussion}

SM metabolism is a novel signal transduction pathway that has an important impact on cell proliferation and apoptosis. This study demonstrates that a high fat diet reduced the activities of alkaline, neutral and acid SMases, neutral ceramidase, and caspase- 3 in rat colonic mucosa. Among the SMases, the alkaline SMase was the most reduced. Some of the effects were enhanced by nonfat components of beef and reversed by fiber (cellulose). However, the experimental diets did not reduce the level of alkaline phosphatase in the colon of rats. These findings might be important because it has been reported that the activity of alkaline SMase is reduced in human colonic cancer tissues and the colonic mucosa of patients with familial adenomatous polyposis [11, 12].

Apart from the reduction of SMase activity, the fat diet also reduced the activity of colonic neutral ceramidase. Neutral ceramidase is a brush border enzyme [21] that is distributed in parallel to alkaline SMase in the gut [22]. Alkaline phosphatase is similar to alkaline SMase and ceramidase in that it is a brush border enzyme [21]; however, its activity was not changed after consumption of any of the diets, thus indicating that the reductions of alkaline SMase and ceramidase activities were not a consequence of general alteration of the brush border enzyme system but rather appears to be a specific action caused by these diets.

Ceramide is a novel lipid messenger that may inhibit cell proliferation, induce cell differentiation and cause apoptosis [2, 23, 24]. It has been shown that a decrease of three types of SMase activities may attenuate SM digestion in the intestinal lumen in SM hydrolysis in the cells, leading to a low level of ceramide. Thus, the decrease of ceramidase activity caused by a fat diet as measured in this study may be a secondary change.

The fat, fat plus beef, and fat plus fiber diets all reduced the activity of alkaline SMase, while the fat and fat plus beef diets reduced the activity of the neutral and acid SMases. The fat plus fiber diet did not cause significant reduction in the activities of either neutral or acid SMases. The fat plus beer diet induced the greatest reduc- tion in the three types of SMases, probably due to the presence of fat in the beef. Previous studies have shown that the soluble fiber psyllium is effective in inhibiting colonic carcinogenesis [25]. Our findings in this study are consistent with this report.

The present study also indicates that both beef and fiber in the fat diet affect the activities of SMase (fig. 1) and neutral ceramidase (fig. 2). Fiber in the fat diet prevented the reductions of acid and neutral SMase activities caused by fat but not that of alkaline SMase. There are many types of fiber, and in this study, we only tested the role of cellulose, which is a nonstarch insoluble polysaccharide [26]. Although cellulose has been shown to have anticarcinogenic effect on colonic mucosa [25], different types of fiber may have different effects on colon cancer development [26, 27]. Soluble fiber such as pectin has recently been shown to induce apoptosis in colonic tissues [28] and soluble fiber psyllium is more effective than cellulose in terms of inhibition of colonic carcinogenesis [25]. Whether pectin and psyllium may increase alkaline SMase activity in normal diet or restore the reduction of the enzyme caused by a fat diet is of interest for further investigation.

Previous studies have found that beef increases the risk of colon cancer [1]. Although it is recognized that beef normally contains high fat, it has not been clearly established whether the carcinogenic effect of beef is contributed by the fat content. In this study, replacing casein with beef (low fat) protein in the fat diet enhanced the reduction of neutral ceramidase activity caused by fat but had no significant effects on that of SMase. The results indicate that a nonfat factor in beef may strongly inhibit ceramidase activity. However, since the beef supplement is not fat-free, the possibility that a small amount of beef fat present in the diet may influence those results cannot be excluded. The negative effect of dietary beef on SMase that we observed concurs with a recent study by Pajari et al. [29].

In our study, the fat plus fiber diet did not change the activity of caspase-3 (fig. 4A). Avivi-Green et al. [28] demonstrated that pectin, a soluble fiber, induced upregulation of caspase- 3 in all colonocyte populations in both normal rats and rats treated with 1,2-dimethylhydrazine. Thus, dietary fiber, both water-insoluble and -soluble, affects caspase- 3 activity in the colon.

The factor that affects the caspase- 3 activation in this study remains elusive. Although it is still a matter of controversy, ceramide is considered a lipid messenger that can induce apoptosis by multiple signaling pathways, including activation of caspase-3 [30]. Recently Rodri- 
guez-Lafrasse et al. [31] confirmed in several cell lines that ceramide formation occurred before activation of caspase- 8 and caspase- 3 and that lack of ceramide formation failed to induce apoptosis even in the presence of caspase- 8 activation. In our study, significant decreases in three types of SMase by the fat diet may decrease the ceramide levels in the colonic cells, which could be a factor leading to reduction of caspase- 3 activity. However, other factors cannot be excluded, particularly bile acids and short chain fatty acids in the colon, which have been shown to impact the caspase cascade. The levels of these two factors are significantly altered by dietary fat and fiber [32, 33].

It is well known that development of colonic cancer is associated with a progressive resistance to apoptosis. Several enzymes are responsible for induction of apoptosis, and caspase- 3 is the key enzyme in the execution phase of apoptosis [34]. The enzyme is expressed at a considerable level in the colonic mucosa [35]. The reduction of caspase- 3 activity after fat and fat with beef diets, as found in this study, could put the colonic mucosa into a state that favors proliferation and is resistant to apoptosis.

\section{Conclusion}

Fat, beef and fiber significantly affect the enzymes responsible for SM metabolism and apoptosis in the colon. The effects may have implications in colonic tumorigenesis related to dietary factors.

\section{Acknowledgments}

The work was supported by grants from Swedish Medical Research Council (12156 and 03696), Swedish Cancerfonden (000307), the Albert Påhlsson Foundation, Gunnar Nilsson's Cancer Foundation, Swedish Medical Association and University Hospital of Lund. Dr. Liping Yang is a visiting scholar from the Department of Physiology, Zunyi Medical College, Zunyi, China.

\section{References}

1 Lipkin M, Reddy B, Newmark H, Lamprecht S: Dietary factors in human colorectal cancer. Annu Rev Nutr 1999;19:545-586.

2 Hammun YA, Linardic CM: Sphingolipid breakdown products: Anti-proliferative and tumor-suppressor lipids. Biochim Biophys Acta 1993; 1154:223-236.

3 Hannun YA, Obeid LM: Ceramide: An intracellular signal for apoptosis. Trends Biochem Sci 1995;20:73-77.

4 Kolesnick RN, Kronke M: Regulation of ceramide production and apoptosis. Annu Rev Physiol 1998;60:643-665.

5 Hassler DF, Bell RM: Ceramidases: Enzymology and metabolic roles. Adv Lipid Res 1993;26: 49-57.

6 Merrill AH Jr, Schmelz EM, Wang E, Schroeder JJ, Dillehay DL, Riley RT: Role of dietary sphingolipids and inhibitors of sphingolipid metabolism in cancer and other diseases. $\mathrm{J}$ Nutr 1995; 125:1677S-1682S.

7 Duan RD: Sphingomyelin hydrolysis in the gut and clinical implications in colorectal tumorigenesis and other gastrointestinal diseases. Scand J Gastroenterol 1998;33:673-683.

8 Dudeja PK, Dahiya R, Brasitus TA: The role of sphingomyelin and sphingomyelinase in 1,2dimethylhydrazine-induced lipid alterations of rat colonic plasma membranes. Biochim Biophys Acta 1986;863:309-312.

9 Dillehay DL, Webb SK, Schmelz EM, Merrill AH: Dietary sphingomyelin inhibits 1,2-dimethylhydrazine-induced colon cancer in $\mathrm{CF} 1$ mice. J Nutr 1994;124:615-620.
10 Schmelz EM, Dillehay DL, Webb SK, Reiter A, Adams J, Merrill AH Jr: Sphingomyelin consumption suppresses aberrant colonic crypt foci and increases the proportion of adenomas versus adenocarcinomas in $\mathrm{CF} 1$ mice treated with 1,2-dimethylhydrazine: Implications for dietary sphingolipids and colon carcinogenesis. Cancer Res 1996;56:4936-4941.

11 Hertervig E, Nilsson A, Nyberg L, Duan RD: Alkaline sphingomyelinase activity is decreased in human colorectal carcinoma. Cancer 1997;79:448-453.

12 Hertevig E, Nilsson Å, Björk J, Hultkrantz R, Duan RD: Familial adenomatous polypopsis is associated with a marked decreased in alkaline sphingomyelinase activity: A key factor to the unrestrained cell proliferation. $\mathrm{Br} \mathrm{J}$ Cancer 1999;81:232-236.

13 Stennicke HR, Salvesen GS: Properties of the caspases. Biochim Biophys Acta 1998;1387: 17-31.

14 Stoffel W: Chemical synthesis of choline-labeled lecithins and sphingomyelins. Methods Enzymol 1975;36:533-541.

15 Nyberg L, Farooqi A, Blackberg L, Duan RD, Nilsson A, Hernell O: Digestion of ceramide by human milk bile salt-stimulated lipase. J Pediatr Gastroenterol Nutr 1998;27:560-567.

16 Mutanen M, Pajari AM, Oikarinen SI: Beef induces and rye bran prevents the formation of intestinal polyps in $\mathrm{Apc}(\mathrm{Min})$ mice: Relation to beta-catenin and PKC isozymes. Carcinogenesis 2000;21:1167-1173.
17 Duan RD, Nyberg L, Nilsson Å: Alkaline sphingomyelinase activity in rat gastrointestinal tract: Distribution and characterization. Biochim Biophys Acta 1995;1259:49-55.

18 Duan RD, Nilsson Å: Enzymes hydrolysing sphingolipids in gastrointestinal tract. Methods Enzymol 1999;311:276-286.

19 Belfrage P, Vaughan M: Simple liquid-liquid partition system for isolation of labeled oleic acid from mixtures with glycerides. J Lipid Res 1969;10:341-344.

20 Cheng Y, Tauschel HT, Nilsson Å, Duan RD Ursodeoxycholic acid increases the activities of alkaline sphingomyelinase and caspase- 3 in rat colon. Scand J Gastroenterol 1999;34:915920.

21 Nilsson $\AA$ : The presence of sphingomyelin- and ceramide-cleaving enzymes in the small intestinal tract. Biochim Biophys Acta 1969;176: 339-347.

22 Lundgren P, Nilsson Å, Duan RD: Distribution and properties of neutral ceramidase activity in rat intestinal tract. Dig Dis Sci 2001;46: 765-772.

23 Schmelz E, Bushnev A, Dillehan DL, Sullards M, Liotta D, Merrill AH: Ceramide-beta- $D$ glucuronide: Synthesis, digestion, and suppression of early markers of colon carcinogenesis. Cancer Res 1999:59:5768-5772.

24 Veldman RJ, Klappe K, Hoekstra D, Kok JW: Metabolism and apoptotic properties of elevated ceramide in HT29rev cells. Biochem J 1998;331:563-569. 
25 Roberts-Andersen J, Mehta T, Wilson RB: Reduction of DMH-induced colon tumors in rats fed psyllium husk or cellulose. Nutr Cancer 1987;10:129-136.

26 Kim YI: AGA technical review: Impact of dietary fiber on colon cancer occurrence. Gastroenterology 2000;118:1235-1257.

27 Wijnands MV, Appel MJ, Hollanders VM, Woutersen RA: A comparison of the effects of dietary cellulose and fermentable galacto-oligosaccharide, in a rat model of colorectal carcinogenesis: Fermentable fibre confers greater protection than non-fermentable fibre in both high and low fat backgrounds. Carcinogenesis 1999 20:651-656.
28 Avivi-Green C, Madar Z, Schwartz B: Pectinenriched diet affects distribution and expression of apoptosis-cascade proteins in colonic crypts of dimethylhydrazine-treated rats. Int $\mathbf{J}$ Mol Med 2000;6:689-698.

29 Pajari AM, Häkkänen P, Duan R-D, Mutanen $\mathrm{M}$ : Role of red meat and arachidonic acid in protein kinase $\mathrm{C}$ activation in rat colonic mucosa. Nutr Cancer 1998;32:86-94.

30 Yoshimura S, Banno Y, Nakashima S, Takanaka K, Sakai H, Nishimura Y, Sakai N, Shimizu S, Eguchi Y, Tsujimoto Y, Nozawa Y: Ceramide formation leads to caspase-3 activation during hypoxic PC12 cell death: Inhibitory effects of $\mathrm{Bcl}-2$ on ceramide formation and caspase- 3 activation. J Biol Chem 1998;273:6921-6927.

31 Rodriguez-Lafrasse C, Alphonse G, Broquet P, Aloy MT, Louisot P, Rousson R: Temporal relationships between ceramide production, caspase activation and mitochondrial dysfunction in cell lines with varying sensitivity to antiFas-induced apoptosis. Biochem J 2001;357: 407-416
32 Schlottman K, Wachs FP, Krieg RC, Kullmann F, Scholmerich J, Rogler G: Characterization of bile salt-induced apoptosis in colon cancer cell lines. Cancer Res 2000;60:4270-4276.

33 Avivi-Green C, Polak-Charcon S, Madar Z, Schwartz B: Apoptosis cascade proteins are regulated in vivo by high intracolonic butyrate concentration: Correlation with colon cancer inhibition. Oncol Res 2000;12:83-95.

34 Green DR: Apoptotic pathways: The roads to ruin. Cell 1998;94:695-698.

35 Krajewska M, Wang HG, Krajewski S, Zapata JM, Shabaik A, Gascoyne R, Reed JC: Immunohistochemical analysis of in vivo patterns of expression of CPP32 (caspase-3), a cell death protease. Cancer Res 1997;57:1605-1613. 